
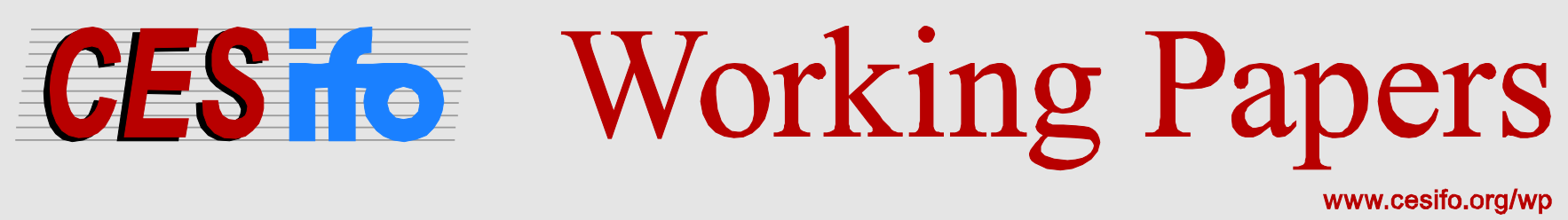

\title{
How the Tight Oil Boom Has Changed Oil and Gasoline Markets
}

\author{
Lutz Kilian
}

\author{
CESIFO WORKING PAPER NO. 6380 \\ CATEGORY 10: ENERGY AND CLIMATE ECONOMICS \\ FEBRUARY 2017
}

An electronic version of the paper may be downloaded

- from the SSRN website:

- from the RePEc website:

- from the CESifo website:

www.SSRN.com

www.RePEc.org

www.CESifo-group.org/wp 


\title{
How the Tight Oil Boom Has Changed Oil and Gasoline Markets
}

\begin{abstract}
Starting in late 2008, the U.S. production of tight oil surged, causing a renaissance in the U.S. oil sector that few industry analysts had anticipated. This tight oil boom reduced the dependence of the United States on petroleum imports and allowed it to become a major exporter of gasoline and diesel fuel. Since mid-2014 the global real price of crude oil has experienced a large and sustained decline. This review article addresses several questions of general interest. First, to what extent was the recent oil price decline caused by the tight oil boom? Second, how did the tight oil boom affect the price of gasoline in global markets and in the United States? Third, what determines the investment response of the oil sector to oil price fluctuations? Fourth, how has the tight oil boom affected the transmission of oil price shocks to the U.S. economy? Finally, what are the implications of the U.S. tight oil boom for European oil importing economies?
\end{abstract}

JEL-Codes: Q430, Q330.

Keywords: tight oil, shale oil, oil price, gasoline price, oil investment, real GDP growth.

\author{
Lutz Kilian \\ Department of Economics \\ University of Michigan \\ 611 Tappan Street \\ USA - Ann Arbor, MI 48109-1220 \\ lkilian@umich.edu
}

February 5, 2017 


\section{Introduction}

Starting in late 2008, the U.S. production of tight oil surged, causing a renaissance in the U.S. oil sector that few industry analysts had anticipated. This tight oil boom reduced the dependence of the United States on petroleum imports and allowed it to become a major exporter of gasoline and diesel fuel. It even caused the United States to abandon by the end of 2015 its long-standing policy of prohibiting exports of domestically produced crude oil. It also changed the geopolitical position of the United States, allowing the country to disengage to a larger degree from political conflicts in the Middle East.

As the global price of crude oil declined from \$150 (in December 2016 dollars) in June 2014 to under $\$ 50$, the question arose to what extent this oil price decline was caused by the tight oil boom, along with growing concerns about the continued profitability of U.S. tight oil producers at these much lower oil prices. At the same time, there was much interest in the question of whether the tight oil boom had fundamentally changed the transmission of oil price shocks to the U.S. economy, including the question of whether lower oil prices had been passedthrough to lower gasoline prices.

These developments and questions have been discussed in a number of recent studies including Fattouh (2014), Borenstein and Kellogg (2014), Brown et al. (2014), Kleinberg et al. (2016), Baumeister and Kilian (2016, 2017), Baumeister, Kilian and Zhou (2017), and Kilian (2016, 2017), among others. This review article summarizes some of the key insights emerging from this literature. The article is intended to be accessible to a general audience. Readers interested in more detailed analysis and in the underlying econometric models are referred to the references above.

The remainder of the article is organized as follows. Section 2 explains what the term 
tight oil (also known as shale oil) refers to, summarizes the quantitative importance of U.S. tight oil production, and provides some institutional background that helps understand how the tight oil boom has affected the prices of oil and gasoline. In section 3, I quantify by how much the tight oil boom has lowered oil and gasoline prices. I stress that the U.S. gasoline price has been determined by the Brent price rather than the WTI price. Thus, the additional decline in the WTI price relative to the Brent price during 2011-2015 caused by the tight oil boom was not being passed on to the retail gasoline price. Section 4 reviews the response of the U.S. economy to the decline in the global price of oil after June 2014, highlighting the role of the tight oil sector. Section 5 examines in more detail the sensitivity of the tight oil sector to oil price fluctuations. Section 6 makes the case for a nonlinear relationship between oil prices and oil investment. Section 7 discusses the implications of the decline in the Brent price of crude oil on European oil importers. The concluding remarks are in section 8.

\section{Background}

Before addressing the substantive questions raised in the introduction, it is useful to explain what is meant by "tight oil", how this oil differs from other types of crude oil, and what the U.S. tight oil boom refers to.

\subsection{What Is Tight Oil?}

The term tight oil (or shale oil) is commonly used by the oil industry and by government agencies to refer to crude oil extracted by certain techniques that differ from those used in conventional oil production. Conventional oil production is designed to extract crude oil from permeable rock formations. After drilling a vertical borehole, the oil contained in the adjacent rock formations flows into the borehole, where it can be collected and pumped to the surface. This technique fails when dealing with crude oil trapped in rock formations characterized by low 
permeability, also colloquially referred to as tight rock. Tight oil producers overcome this challenge by a combination of technological advances. After drilling a deep vertical borehole, they drill horizontally into the tight rock, before hydraulically fracking the tight rock. The latter technique involves pumping a mixture of water, sand, and toxic chemicals under high pressure into the borehole. Under the pressure of this fracking fluid, the tight rock cracks and small fissures open up that allow the oil trapped in the rock to escape and flow into the borehole. The purpose of including sand in the fracking fluid is for the sand grains to keep these rock fissures open, even after the fracking fluid has been removed to be recycled or to be disposed of in separate disposal wells far below the groundwater level. The combination of horizontal drilling and hydraulic fracturing (or "fracking" for short) allows oil producers to access crude oil that geologists knew about for many years, but that heretofore had been inaccessible.

To date, commercial tight oil production has been largely limited to the United States. As with any large scale industrial operation, tight oil production may be associated with environmental damages and other externalities, especially in the absence of a proper regulatory environment. Particular concerns have been the possible contamination of ground water due to improper handling of the fracking fluid as well as an increase in seismic activity in areas near fracking sites. For example, homeowners in parts of Texas and Oklahoma have experienced a sharp increase in the frequency of earthquakes after the expansion of tight oil production. Recent research has determined that these earthquakes were caused not by the fracking activity itself, but rather by oil companies disposing of used fracking fluid as well as other wastewater in disposal wells. If these disposal wells are inadvertently located near fault lines, the risk of earthquakes increases, as the weight of these fluids creates pressures underground. ${ }^{1}$

\footnotetext{
${ }^{1}$ The development of tight oil production was preceded by the development of tight (natural) gas (see Mason et al. 2015; Hausman and Kellogg 2015). The technology used in tight gas production is similar to that used in tight oil
} 


\subsection{How Different Is Tight Oil from Conventionally Produced Crude Oil?}

The quality of crude oil can generally be characterized along two dimensions. One is the oil's density (ranging from light to heavy), which is typically measured according to the American Petroleum Institute (API) gravity formula; the other is its sulfur content (with sweet referring to low sulfur content and sour to high sulfur content). Commonly used oil benchmarks such as Brent crude oil or West Texas Intermediate (WTI) crude oil are all sweet and light with an API gravity value of less than $40 .^{2}$ In contrast, tight oil consists of light sweet crude with at most 45 API, ultra-light sweet crude with an API of about 47, and condensates with an API as high as 60 . The higher the API gravity, the lighter is the crude oil. This means that tight oil is by no means a perfect substitute for conventional light sweet crude oil from the point of view of the refiners that transform this crude oil into the products that firms and consumers buy such as gasoline, diesel fuel, heating oil, or jet fuel. Nor is it a substitute for heavier and more sour crudes imported from Venezuela, Mexico or Saudi Arabia or the heavy crudes produced from oil sands in Canada favored by some U.S. refineries. This means that statistics measuring total oil production by aggregating the barrels produced of different types of crude oil have to be taken with a grain of salt. It also means that supply-demand imbalances may vary across different segments of the oil market and that different types of crude oil need not be subject to the law of one price, even after accounting for transportation costs. The evolution of the price of oil in recent years can only be understood by keeping in mind these differences across different types of crude oil, because not all U.S. oil refineries are capable of processing the very light sweet crude oil that makes up much of U.S. tight oil production. Before discussing the effect of the tight oil boom on the price of oil,

production, which allowed much of the equipment used in tight gas production to be shifted to tight oil production after late 2008, when the U.S. price of natural gas continued to decline.

2 The WTI price is a benchmark that is widely used by oil market participants. It refers to the spot price of WTI crude oil for immediate delivery in Cushing, Oklahoma. The Brent benchmark relates to a similar, if slightly heavier and more sour type of light sweet crude oil from the North Sea that is traded in Europe. 
however, it is useful to quantify the surge in tight oil production and, as a result, in total U.S. oil production.

\subsection{The U.S. Tight Oil Boom}

The upper panel of Figure 1 shows the evolution of the average daily U.S. production of tight oil since January 2007. Between November 2011 and March 2015, U.S. tight oil production increased by a staggering $287 \%$. Figure 1 shows that the tight oil boom is far from over. Notwithstanding a 15\% decline from its peak level, as of early 2017 production remains very high. The lower panel shows the spot price of WTI crude oil (expressed in December 2016 dollars to control for inflation), which is a commonly used benchmark for oil market participants. Of particular interest is how slow tight oil production has been to respond to the decline in the real WTI price since June 2014. This resilience is explained by a combination of remarkable gains in productivity and aggressive cost cutting, which allowed tight oil producers to remain in business at far lower oil prices than analysts thought possible in June 2014. Although the number

of bankruptcies in the industry increased sharply and although there have been mounting signs of financial stress, as many tight oil producers found it more difficult to borrow, the industry as a whole weathered the oil price decline largely intact. Much of the burden of the adjustment fell on companies providing support services to the oil industry.

As Figure 2 shows, the tight oil boom that started in November 2008 helped reverse a long-standing decline in U.S. total oil production, defined to include both tight oil and conventional crude oil. By March 2015, total U.S. oil production had reached levels not seen since the early 1970s, allowing the oil sector to substitute domestic crude oil for oil imports from African oil producers, in particular, and to a lesser extent from Arab oil producers. Moreover, after 2014 an increasing volume of U.S. tight oil production was being exported. Although the 
long-standing U.S. ban prohibiting exports of domestically produced crude oil (with some exceptions mainly for exports to Canada) remained in effect until the end of 2015, in 2014 and 2015 the Obama administration approved an oil swap with Mexico as well as limited exports of crude oil to alleviate the glut of domestically produced tight oil, before the ban was finally lifted altogether in January 2016.

\section{The Response of the Price of Oil to the Tight Oil Boom}

The tight oil boom was facilitated by the use of horizontal drilling and fracking. Although these techniques had been used before, one at a time, their combined use is a fairly recent technological innovation. The tight oil boom is a classical example of a technological shock causing an exogenous shift in the supply of a good. By October 2016, U.S. tight oil production had increased to $6 \%$ of world oil production. Thus, one would expect the tight oil boom, all else equal, to have lowered the global price of crude oil. The question is by how much. In discussing the effect of the U.S. tight oil boom on the price of oil, it is important to distinguish between its effect on the global price of oil (as measured by the spot price of Brent crude oil) and its effect on the U.S. price of oil (as measured by the spot price of WTI crude oil).

\subsection{How the Tight Oil Boom Affected the WTI Price Relative to the Brent Price}

Figure 3 shows the evolution of three benchmarks for the price of light sweet crude oil. The Brent price may be viewed as a proxy for the global price of crude oil. The WTI price is a measure of the price of crude oil at the hub of U.S. oil trading in Cushing, Oklahoma. Finally, the price of Louisiana Light Sweet (LLS) crude oil refers to the price of oil locally produced along the coast of the Gulf of Mexico and traded in Louisiana. Traditionally, these three prices have been moving largely in step. This pattern persists until the end of 2010 and resumes in early 2016. Between 2011 and late 2015, however, there is an interlude during which some of these 
prices differed substantially. During phase 1, which lasted from December 2010 to July 2013, WTI oil was trading at a steep discount relative to Brent. LLS oil, in contrast, was trading much closer to international benchmarks such as Brent. This pattern changed in phase 2, which lasted from August 2013 to December 2015. Whereas WTI oil still traded at a discount relative to Brent, albeit less so over time, during this phase the LLS price began to track closely the WTI price rather than the Brent price.

This pattern is no accident. It reflects changes in oil market fundamentals caused by the increasing availability of tight oil in Cushing, Oklahoma, after 2010. In a nutshell, the problem was that more tight oil arrived in Cushing than could be processed by refiners locally. Traditionally, oil had been shipped north by pipeline from the oil tanker terminals on the Gulf Coast to Cushing, not from Cushing south to the Gulf Coast refineries. These pipelines are in essence one-way streets because oil in the pipeline can flow only in one direction. Nor was there enough capacity for shipping the tight oil to the Gulf Coast by rail. Because there was no pipeline or other transportation infrastructure in place to move the tight oil from Cushing south to the U.S. refineries on the Gulf Coast or east to the U.S. refiners on the East Coast, local supply exceeded local demand and the price of light sweet crude oil in Cushing, Oklahoma, dropped relative to international benchmarks such as Brent. In contrast, LLS oil on the coast directly competed with imported Brent oil, allowing local oil producers to charge the same high price that refiners along the Gulf coast payed for imported Brent crude oil. Thus, the global oil market had fragmented. The central United States formed one oil market, and the rest of the United States remained part of the global oil market.

This situation changed in mid-2013 as a result of two developments. One was that an existing pipeline that used to transport oil from the Gulf ports to Cushing was reversed and that 
new pipelines linking Texas refineries to tight oil producers were constructed, allowing the tight oil arriving in Cushing to be moved to the Gulf Coast. The other development was that rail transport of tight oil surged. By 2013, nearly twice as many carloads of crude oil were transported by rail than in 2012 and more than 40 times as many as in 2008 (see Esser 2014). Likewise, the shipping of crude oil by barge both down the Mississippi and along the U.S. coast surged. A combination of rail and barge shipping allowed tight oil production to reach the refineries along the East Coast, which were better prepared for processing light sweet crude oil than the refineries in Texas, which specialized in processing heavier crudes. The surge in the availability of light sweet crudes along the Gulf Coast meant that LLS producers now had to compete against low cost oil from the interior of the country rather than high-priced Brent oil and had to acquiesce to the lower WTI price. In short, what used to be a local glut of oil in Cushing now was transformed into a nationwide glut in the United States, fueled by the tight oil boom.

A potential solution might have been to export this tight oil, given that global demand for crude oil remained high, as evidenced by the higher Brent price. This solution was not feasible. One reason was the existence of a U.S. law prohibiting the export of domestically produced crude oil (with some exemptions at the discretion of the Department of Commerce). This oil export ban had been enacted in 1975, after the 1973/74 oil crisis, in an attempt to insulate the United States from foreign oil price shocks. It is not clear, however, whether the oil transportation infrastructure would have sufficed for large scale exports, even in the absence of the oil export ban. In the end, market participants came up with a less direct solution, which involved refiners purchasing more oil than was needed to satisfy domestic U.S. demand, to refine this oil, and to export the refined products to Europe and Latin America. This approach was perfectly legal because exports of gasoline and diesel were not covered by the U.S. ban on crude 
oil exports.

The reason why the gap between the Brent price on the one hand and the prices of WTI and LLS on the other gradually closed was twofold. One the one hand, increased U.S. tight oil production over time displaced crude oil exports from Arab oil producing countries, reducing demand for oil in the rest of the world and lowering the Brent price, because the United States no longer relied as heavily on crude oil imports. On the other hand, U.S. exports to the rest of the world of refined products made from domestically produced crude oil caused other countries to cut back on their crude oil imports as well, lowering global demand for oil even further. The downward pressure on the Brent price of oil in conjunction with the upward pressure on the WTI price, as refiners processed ever larger quantities of tight oil, eroded the Brent-WTI price spread in the second half of 2014 and in 2015. By the end of 2015, the U.S. oil export ban was lifted, helping to reestablish arbitrage between the U.S. oil market and the global oil market, with arbitrage being constrained only by the remaining bottlenecks in transporting oil.

An interesting question is why the oil export ban was lifted so late. The answer is that refiners had aggressively lobbied for the continuance of this ban, as long as the WTI price remained below the Brent price. The reason is simple. Because domestic oil could be purchased below world market prices, refiners could produce gasoline and diesel at lower cost than their foreign competitors, which gave them a competitive advantage in the global gasoline market. The gap between the Brent price and the WTI price rose and fell over time, depending on whether transportation and refining capacity was able to keep up with additional tight oil production or not. When the Brent-WTI spread finally all but vanished by late 2015, so did the refiners' resistance to lifting the oil export ban. For all practical purposes, the ban had ceased to be economically relevant. 
One might have thought that U.S. refiners would have passed on their cost savings to U.S. consumers of gasoline and diesel fuel, as long as the Brent price exceeded the WTI price. This did not happen. One explanation is that the marginal barrel of oil purchased by refineries on the East Coast remained high-priced Brent crude oil (see Borenstein and Kellogg 2014). A complementary explanation is that, as long as the gasoline intended for the domestic market may be sold abroad for a higher price, it makes no sense for a profit maximizing refiner to lower the price of gasoline in the United States (see Kilian 2016). In other words, the U.S. gasoline price was determined in global markets, whereas the price of crude oil during 2011-15 was not. The resulting economic surplus was almost entirely appropriated by the refiners. The U.S. price of gasoline ultimately declined only to the extent that the Brent price of oil declined. Brown et al. (2014) make the case that lifting the oil export ban is likely to lower further the price of gasoline by 1.7 to 4.5 cents per gallon, reflecting the increased efficiency of U.S. refinery operations, but it may be several years before these gains are realized.

\subsection{How the Tight Oil Boom Has Affected the Brent Price}

The most striking pattern in Figure 3 is not the closing of the gap between the Brent and the WTI price, but the steep and sustained decline in all oil prices, including the Brent price, after June 2014. It may be tempting to think that this decline was caused primarily by the tight oil boom, but this is not the case. A recent econometric study by Kilian (2017) shows that the cumulative decline in the real price of oil since June 2014 has been driven by a combination of positive oil supply shocks, negative shocks to the storage demand for oil reflecting expectations of lower oil prices, and negative shocks to consumption demand associated with an unexpected slowing of the global economy.

Figure 4 quantifies the cumulative effect of each type of shocks on the real price of oil 
since January 2014. The results in Figure 4 corroborate those in Baumeister and Kilian (2016) based on a different methodology. Baumeister and Kilian provided independent evidence that a slowdown in the global demand for oil was a major contributor to this specific oil price decline in addition to a mix of shocks to actual and/or expected global oil supplies prior to July 2014 and a shift in oil price expectations in July 2014. They also were able to reject beyond a reasonable doubt the common notion that the decline in the price of oil in December 2014, in particular, was triggered by the announcement that Saudi Arabia would not reduce its oil production. There is no indication that market participants were surprised by this announcement and responded by selling off oil stocks. Rather this decline coincided with a sharp drop in global real economic activity.

Figure 4 highlights that oil supply shocks played an important role in explaining the decline in the real price of oil since June 2014, but these oil supply shocks reflect unexpected changes in oil production worldwide and cannot simply be attributed to the tight oil boom. Although the United States were responsible for some of the global oil production increase since 2008, accounting for a cumulative increase of 4.3 million barrels per day (mbd) by September 2015, there have also been notable production increases in Iraq (2.07 mbd), Saudi Arabia (1.23 mbd), Russia (0.79 mbd) and Canada (0.73 mbd) that were unrelated to the tight oil boom (see Kilian 2017).

Thus, if we want to assess the effect of the U.S. tight oil boom on the Brent price of oil, we need to decompose the results in Figure 4 further. The question of interest is how different the Brent price of crude oil would have been, if all oil producers other than the United States had maintained their observed oil production levels, but the U.S. tight oil boom had never happened. This counterfactual level of global oil production may be constructed simply by subtracting U.S. 
tight oil production after November 2008 from the observed level of global oil production, as shown in Figure 5. Given that the tight oil boom reflected oil supply shocks driven by technological innovation, it is natural to think of the causes of this boom as a sequence of oil supply shocks between November 2008 and August 2015.

Given a suitable structural model of the oil market such as the model proposed by Kilian and Lee (2014), we may then infer the sequence of oil supply shocks required to produce the counterfactual path of oil production, holding constant the remaining structural shocks in the model. Provided this counterfactual shock sequence does not differ systematically from historical shock sequences, we can feed these supply shocks into the structural model to determine how much higher the price of oil would have been after November 2008 under the counterfactual than actually observed. This exercise was conducted in Kilian (2017). The results are summarized in Figure 6. Figure 6 shows that the cumulative effect of the tight oil boom on the Brent price started building gradually after 2010 and reached a peak in mid-2014, before declining in late 2014. Whereas in mid-2014 the Brent price was lower by $\$ 10$ than it would have been in the absence of the fracking boom, by mid-2015 this price differential had fallen to $\$ 5$.

Figure 6 also demonstrates that a very similar price decline would have occurred between July 2014 and January 2015 even in the absence of increased U.S. tight oil production, implying that increased U.S. tight oil production was not the main cause of this price decline. This point is important because it implies that the effect of the tight oil boom on the global price of gasoline and therefore on the U.S. price of gasoline has been quite limited, especially after June 2014.

\section{How the Tight Oil Boom Affected the U.S. Economy}

Although the tight oil boom was not the main cause of the decline in the global real price of oil 
that took place after June 2014, the U.S. oil sector played an important role in the transmission of this oil price decline to the U.S. economy.

\subsection{The Traditional View}

The traditional textbook view has been that an unexpected decline in the price of oil should stimulate real GDP growth in oil-importing economies. The main channel of transmission is not so much that oil price declines lower the cost of producing domestic goods and services. In fact, few industries other than refineries depend heavily on the cost of crude oil, and the oil share in real GDP tends to be small. Nowadays much of the oil consumed is used for transportation in the form of oil products such as gasoline, diesel fuel or jet fuel. As Baumeister and Kilian (2017) show, however, even the U.S. commercial transportation sector (trucks, railroads, airlines) has been hardly affected by the recent oil price decline.

Instead, the main channel of transmission is that consumers end up spending less of their income on motor fuel at the gas station. As the global price of crude oil falls, so does the price of gasoline. Given a cost share of crude oil in producing gasoline of about 50\%, a 68 percent cumulative fall in the price of crude oil, for example, would be expected to cause a 34 percent cumulative decline in the price of gasoline, approximately. Lower gasoline prices in turn reduce the amount of money consumers spend on gasoline. To the extent that this money is used to pay for imports of gasoline (or imports of crude oil from which the gasoline is produced), the reduction in gasoline prices reduces the transfer of domestic income abroad. This income now becomes available for additional domestic purchases and stimulates domestic private consumption (see, e.g., Baumeister, Kilian and Zhou 2017). As private consumer spending increases, so does business fixed investment by the non-oil sector. Increased spending in turn stimulates real GDP, if there is slack in the domestic economy. 


\subsection{Why the Investment Spending by Oil Producers Matters}

Recent research has shown that in countries with a sizable domestic oil production sector such as the United States these stimulating effects may be offset by the response of the oil sector. The concern is not the contribution of the domestic oil production to domestic value added, which tends to be small, but rather the investment decisions by oil producers. Baumeister and Kilian (2017) document a 48\% cumulative decline in the investment by the U.S. oil sector (including tight-oil producers) between June 2014 and March 2016. Even after taking account of the small share of oil investment in U.S. real GDP, this reduction in spending has important implications for aggregate spending and economic growth.

Table 1 shows that the cumulative effect on U.S. real GDP growth of the reduced oil investment spending is almost as large as the combined effect of higher private consumer spending and higher non-oil investment spending. The net stimulus for the U.S. economy of 0.17 percent over seven quarters is essentially zero. ${ }^{3}$ Put differently, lower oil prices account for an increase in average U.S. real GDP growth at annual rates of only about 0.1 percentage points. In interpreting these estimates, it should be kept in mind that one of the reasons for the low real price of oil has been the slowing of the global economy, which is reflected in much slower growth in U.S. non-petroleum exports. Controlling for this economic slowdown, average U.S. real GDP growth would have been higher by about 0.4 percentage points at annual rates, but even that estimate is quite modest, highlighting the importance of oil investment spending for the U.S. economy.

\subsection{Other Channels of Transmission}

\footnotetext{
${ }^{3}$ Unlike the corresponding estimates reported in Table 8 of Baumeister and Kilian (2017), the estimates in Table 1 explicitly account for changes in the dependence of the U.S. economy on imports of crude oil and gasoline (also see Baumeister, Kilian, and Zhou 2017). The results are, nevertheless, quite similar.
} 
In contrast, a number of other channels by which the oil sector might affect the rest of the U.S. economy do not appear to be nearly as important as sometimes believed. For example, Baumeister and Kilian (2017) found no evidence that the retrenchment of the oil sector reduced investment spending in other sectors of the U.S. economy. Nor is there any evidence that bad loans to the oil sector undermined the health of the banking system. Perhaps most interestingly there is no evidence that the decline in the real price of oil caused a large increase in unemployment, as oil workers lost their jobs. This is true even in oil-states such as Texas or North Dakota. Table 2 shows that despite a significant reduction in the share of mining jobs in employment, in five of the seven U.S. oil producing states, including the main tight oil producing regions, unemployment fell and in the other two it increased only slightly. For example, the unemployment rate in Texas fell from 5.1\% in June 2014 to 4.3\% in March 2016, which is below the national average, and in North Dakota, the unemployment rate only increased from 2.7 to 3.1 percent. It can be shown that this result is not an artifact of oil workers migrating to other states. Rather it appears to be an indication of these workers having been reintegrated in the job market.

Similarly, there is no evidence that the underutilization of capital in oil-producing states had important effects on real GDP growth. Underutilization arises when equipment sits idle because production stops. For example, the number of U.S. oil rigs is down by 75 percent compared with October 2014, and petroleum rail car loads have dropped by 30\% since September 2014. There is also anecdotal evidence of widespread underutilization of motels, restaurants and other infrastructure servicing oil workers. An economy using less capital by construction will produce less real output. One way of capturing these effects is to compare real GDP growth in the United States to the growth rate obtained after excluding the seven oilproducing states listed in Table 2. As Baumeister and Kilian (2017) show, this difference is only 
0.05 percentage points of average U.S. growth at annual rates, suggesting that these effects are negligible.

\section{How Sensitive Is Investment in the Tight Oil Sector to Oil Price Fluctuations?}

Table 1 highlights that the negative response of fixed investment in the oil sector has been the main reason why the U.S. economy did not grow as much as one would have expected based on the consumption and non-oil investment stimulus. A question of obvious interest is what determines investment decisions in the oil sector in general and in the tight oil sector in particular. Although there is a perception that investment spending by tight oil producers is more price-sensitive than investment spending by conventional oil producers, evidence in Baumeister and Kilian (2017), who compared the 2014-16 episode with the large and sustained oil price decline of 1986-87, suggests that oil investment spending, if anything, has become less responsive to oil price declines during the tight oil boom.

There is no doubt that the production of tight oil may respond more quickly to oil price increases than conventional oil production. These arguments do not necessarily extend to investment decisions in the oil sector, however. The decision to continue to invest in new tight oil production depends on whether the expected price of oil exceeds the long-run marginal cost of oil production. If so, oil production remains profitable and investment continues. Otherwise, investment ceases. One difference from conventional oil production is that the marginal cost of producing tight oil tends to be higher than that for conventional oil production, which, all else equal, suggests that, as the expected price of oil declines, investment by tight oil producers should cease before conventional oil investment.

Another difference, however, is that investment in the tight oil sector has a much shorter horizon. Whereas production from conventional oil wells may continue for 50 years, much of the 
tight oil is extracted in the early stages of fracking, followed by a few years of greatly diminished production. Thus, the investment decision of tight oil producers depends on the expected evolution of the price of oil in the short run only. For new conventional oil investment, in contrast, the price of oil expected at longer horizons also matters. For example, expectations of a longer-term price recovery would tend to make conventional oil investment more robust to oil price declines than tight oil investment. Which type of investment is affected more therefore is ambiguous, in general. In addition, it has to be kept in mind that the uncertainty about the future price of oil may be higher in the short run than in the long run, which would slow investment in tight oil compared with longer-term oil investments. If oil price uncertainty is lower in the short run than in the longer run, in contrast, tight oil investment would be boosted relative to investment in conventional oil.

Finally, we need to remind ourselves that many conventional investment projects (as well as high-cost unconventional investment projects such as deep-sea oil drilling) have long gestation lags. To the extent that these projects were started many years ago, what matters in the current environment is whether these projects would be profitable, if completed. That completion time may be quite short, not unlike that of tight oil investment projects. Costs that have already been sunk into these projects do not affect the decision whether to complete the project, making a comparison with tight oil projects even less straightforward. For all these reasons, it is not clear a priori whether tight oil investment is more responsive to oil price fluctuations than other oil investment.

\section{Is the Transmission of Oil Price Shocks Nonlinear?}

There is a large literature on nonlinearities in the transmission of oil price shocks to the U.S. economy. Many of the conventional economic explanations of such nonlinearities lack strong 
empirical support (see, e.g., Kilian 2014; Baumeister and Kilian 2017; Kilian and Vigfusson 2017). The analysis of the oil price decline after June 2014 suggests that the response of the U.S. economy to unexpectedly low oil prices may be nonlinear for a very different reason. That reason is that the fixed investment by the oil sector under certain conditions may respond more strongly to an unexpected decline in the real price of oil than to an unexpected increase in the real price of oil of the same magnitude. ${ }^{4}$

The usual presumption in models of the transmission of oil price shocks is that the effects of lower oil prices on investment are the larger, the greater the decline in the real price of oil. The discussion in section 5, however, suggests that fixed investment by the domestic oil sector will decline disproportionately, once the expected real price of oil crosses a lower threshold. The reason is that oil investment depends not so much on the extent of the decline in the expected real price of oil, but on whether the real price of oil is expected to fall below the breakeven price, at which the cash flow of the investment is zero. In the latter case, domestic oil investment may cease rather abruptly. Thus, the relationship between the real price of oil and oil investment is inherently nonlinear. In practice, the threshold, beyond which oil investment stops, is likely to be smooth, given that different investment projects have different thresholds, but the economic intuition remains unchanged.

As long as the oil-producing sector in the domestic economy is quantitatively unimportant or the real price of oil is far from the threshold, this nonlinearity may be ignored for all practical purposes. The experience of the United States after June 2014, however, suggests that standard models of the transmission of oil price shocks to the U.S. economy may have to be adapted to account for this nonlinear behavior.

\footnotetext{
${ }^{4}$ This observation was first made by Edelstein and Kilian (2007) in the context of discussing the effects of the 1986 oil price decline on U.S. nonresidential investment.
} 


\section{Implications for European Oil Importers}

To the extent that European oil importers with the exception of Norway and the U.K. do not have an important domestic oil industry, one would expect the decline in the Brent price of crude oil, all else equal, to have a larger stimulative effect on these economies than on the U.S. economy. There are several reasons why this stimulus may be smaller than one might have thought, however. First, one of the determinants of lower oil prices has been a slowdown in the global economy that is likely to slow growth in export-oriented European economies more than in the United States. Second, the Euro has been depreciating against the U.S. dollar after June 2014, offsetting in part the decline in the dollar price of Brent crude oil (see Baumeister and Kilian 2016). Third, given the much larger share of gasoline taxes in European retail gasoline prices, the pass-through from lower oil import prices to retail gasoline prices is much smaller, and hence the response of consumers is more muted.

\section{Concluding Remarks}

Going forward, a question of obvious policy interest is whether higher investment in the U.S. oil sector will help offset the contractionary effect on private consumption of a future recovery of the real price of oil. As discussed in Baumeister and Kilian (2017), the answer to this question depends on how fast oil investment would grow in response to an increase in the real price of oil. This response will depend on the industry's expectations about the future evolution of the real price of oil and on the degree of uncertainty surrounding these expectations. How a recovery of the real price of oil would affect U.S. real GDP growth more generally also depends on the determinants of that recovery. Assuming that this recovery is of a similar magnitude as the cumulative oil price decline after June 2014 and composed of similar oil demand and oil supply shocks, all indications are that the response of the U.S. economy would be largely symmetric. 
For example, one would expect a negative stimulus from consumer and non-oil investment spending. Of course, as noted by Kilian (2009), no two oil price shocks are alike, and there is no reason to expect the composition, magnitude or evolution of the oil demand and oil supply shocks to mirror those in the past. For example, if a recovery of the real price of oil primarily reflected a more robust global economy, the overall effects on the U.S. economy would be less negative than if the oil price recovery were driven mainly by actual or anticipated oil supply shocks. 


\section{References}

Baumeister, C., and L. Kilian (2016), “Understanding the Decline in the Price of Oil since June 2014,” Journal of the Association of Environmental and Resource Economists, 3(1), 131158.

Baumeister, C., and L. Kilian (2017), “Lower Oil Prices and the U.S. Economy: Is This Time Different?” forthcoming: Brookings Papers on Economic Activity, Spring.

Baumeister, C., Kilian, L. and X. Zhou (2017), “Is the Discretionary Income Effect of Oil Price Shocks a Hoax?” manuscript, University of Michigan.

Borenstein, S., and R. Kellogg (2014), “The Incidence of an Oil Glut: Who Benefits from Cheap Crude Oil in the Midwest?” Energy Journal, 35, 15-33.

Brown, S.P.A., Mason, C.F., Krupnick, A., and J. Mares (2014), “Crude Behavior: How Lifting the Export Ban Reduces Gasoline Prices in the United States,” Issue brief 1403-REV. Resources for the Future, Washington, DC.

Edelstein, P., and L. Kilian (2007), “The Response of Business Fixed Investment to Energy Price Changes: A Test of some Hypotheses about the Transmission of Energy Price Shocks,” B.E. Journal of Macroeconomics, 7(1) (Contributions).

Esser, C. (2014), “Rail vs. Pipelines: How to Move Oil,” IEA Energy, 6, 11.

Fattouh, B. (2014), “The U.S. Tight Oil Revolution and its Impact on the Gulf Cooperation Council Countries: Beyond the Supply Shock.” OIES Paper WPM 54, Oxford University.

Hausman, C., and R. Kellogg (2015), "Welfare and Distributional Implications of Shale Gas,” Brookings Papers on Economic Activity, Spring, 71-125.

Kilian, L. (2009), “Not All Oil Price Shocks Are Alike: Disentangling Demand and Supply 
Shocks in the Crude Oil Market,” American Economic Review, 99, 1053-1069.

Kilian, L. (2016), “The Impact of the Shale Oil Revolution on U.S. Oil and Gas Prices,” Review of Environmental Economics and Policy, 10, 185-205.

Kilian, L. (2017), “The Impact of the Fracking Boom on Arab Oil Producers,” forthcoming: Energy Journal

Kilian, L., and T.K. Lee (2014), “Quantifying the Speculative Component in the Real Price of Oil: The Role of Global Oil Inventories,” Journal of International Money and Finance, 42, 71-87.

Kilian, L., and R.J. Vigfusson (2017), ““'The Role of Oil Price Shocks in Causing U.S. Recessions," forthcoming: Journal of Money, Credit, and Banking.

Kleinberg, R.L., Paltsev, S., Ebinger, C.K., Hobbs, D., and T. Boersma (2016), “Tight Oil Development Economics: Benchmarks, Breakeven Points, and Inelasticities,” MIT CEEPR Working Paper No. 2016-12.

Mason, C.F., Muehlenbachs, L.A., and S.M. Olmstead (2015), “The Economics of Shale Gas Development,” Annual Review of Resource Economics, 7, 269-289.

U.S. Energy Information Administration (2017), Monthly Energy Review, January. U.S. Energy Information Administration (2017), Drilling Productivity Report, January. 
Table 1. The Net Stimulus from Unexpectedly Lower Real Oil Prices, 2014Q2-2016Q1

\begin{tabular}{|c|c|c|}
\hline Effect on U.S. & \multicolumn{2}{|c|}{ Percent of Cumulative Real GDP Growth } \\
\hline Private Consur & \multicolumn{2}{|c|}{0.51} \\
\hline Oil-Related Pr & \multicolumn{2}{|r|}{-0.57} \\
\hline Non-Oil Relat & \multicolumn{2}{|r|}{0.19} \\
\hline Petroleum Tra & \multicolumn{2}{|r|}{0.04} \\
\hline Net Stimulus & \multicolumn{2}{|r|}{0.17} \\
\hline \multicolumn{3}{|c|}{$\begin{array}{l}\text { NOTES: The estimates of the stimulus have been adjusted based on a marginal import propensity of } 0.15 \text { and take into account the } \\
\text { share of each expenditure component in real GDP. The response of private consumption and non-oil related private nonresidential } \\
\text { investment was estimated based on the regression model that takes into account the change in consumers' purchasing power, as the } \\
\text { real price of oil fluctuates, as well as changes in the dependence of the U.S. economy on imports of gasoline and crude oil. }\end{array}$} \\
\hline & Unemployment Rate (\%) & $\begin{array}{c}\text { Share of Mining and Logging Jobs } \\
\text { in Employment }\end{array}$ \\
\hline Alaska & -0.4 & -0.4 \\
\hline Montana & -0.3 & -0.5 \\
\hline New Mexico & -0.6 & -1.0 \\
\hline North Dakota & 0.4 & -2.5 \\
\hline Oklahoma & -0.1 & -0.9 \\
\hline Texas & -0.8 & -0.7 \\
\hline Wyoming & 1.0 & -2.1 \\
\hline
\end{tabular}

NOTES: Computed based on U.S. Bureau of Labor Statistics data. 
Figure 1. U.S. Tight Oil Production and the Real WTI Price, 2007.1-2017.2
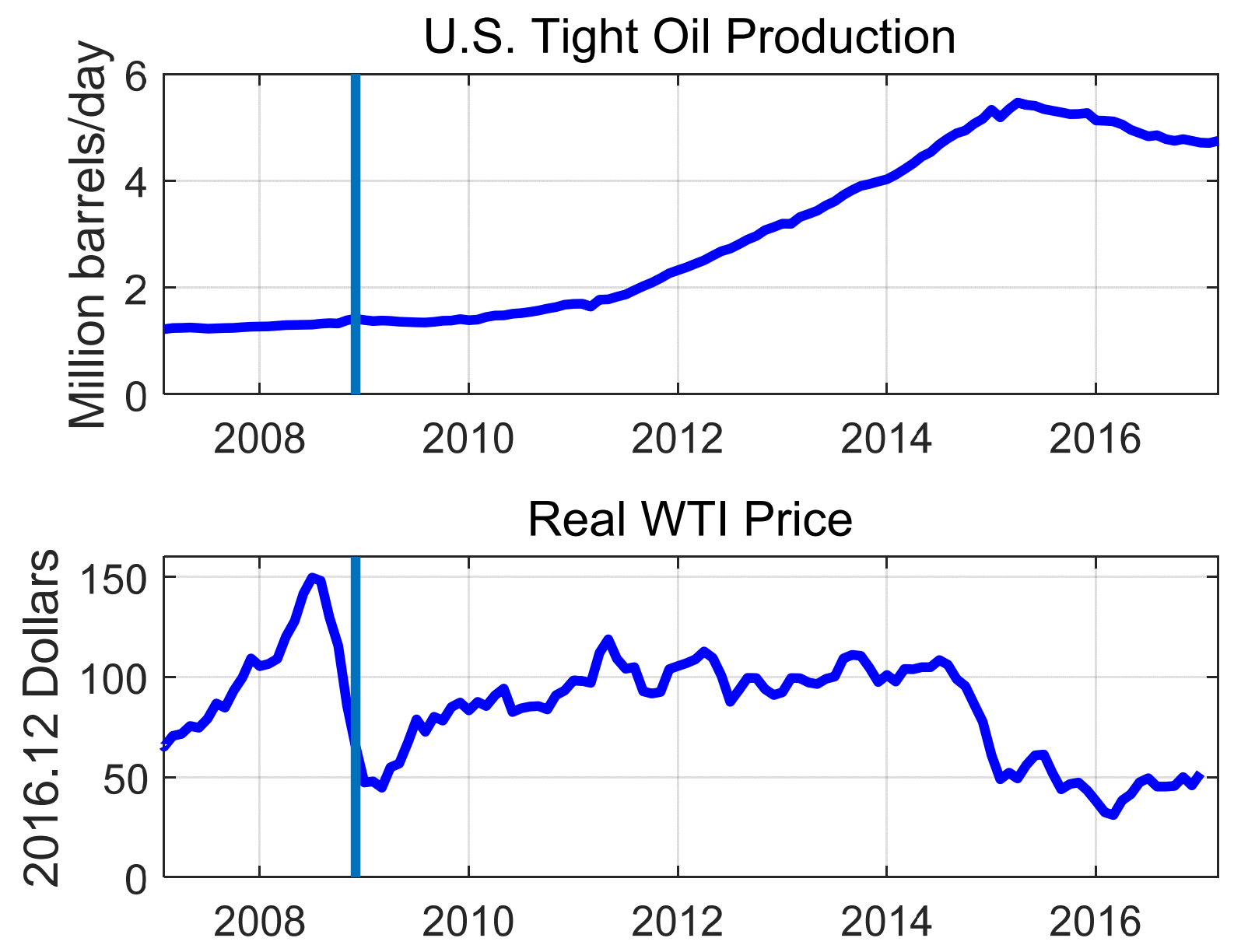

NOTES: The tight oil production data are obtained from U.S. Energy Information Administration’s Drilling Activity Report by adding crude oil production in the seven largest U.S. tight oil producing regions, which account for more than $90 \%$ of U.S. tight oil production. The vertical line marks the beginning of the U.S. tight oil boom in November 2008. 
Figure 2. U.S. Total Oil Production and Trade, 1973.1-2016.12

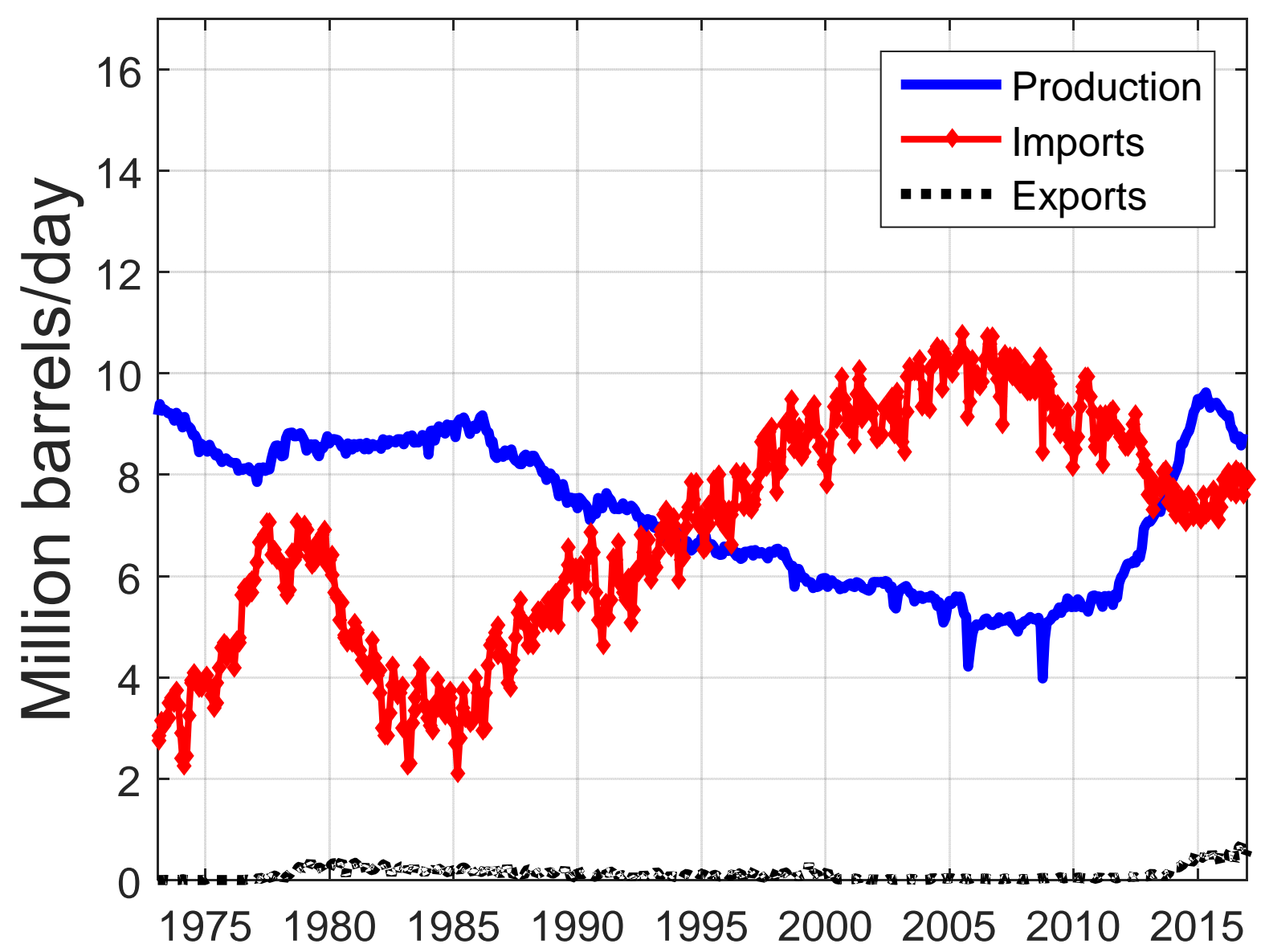

NOTES: All data are from the U.S. Energy Information Administration's Monthly Energy Review. 
Figure 3. Monthly Spot Prices of Crude Oil, 2008.1-2016.12

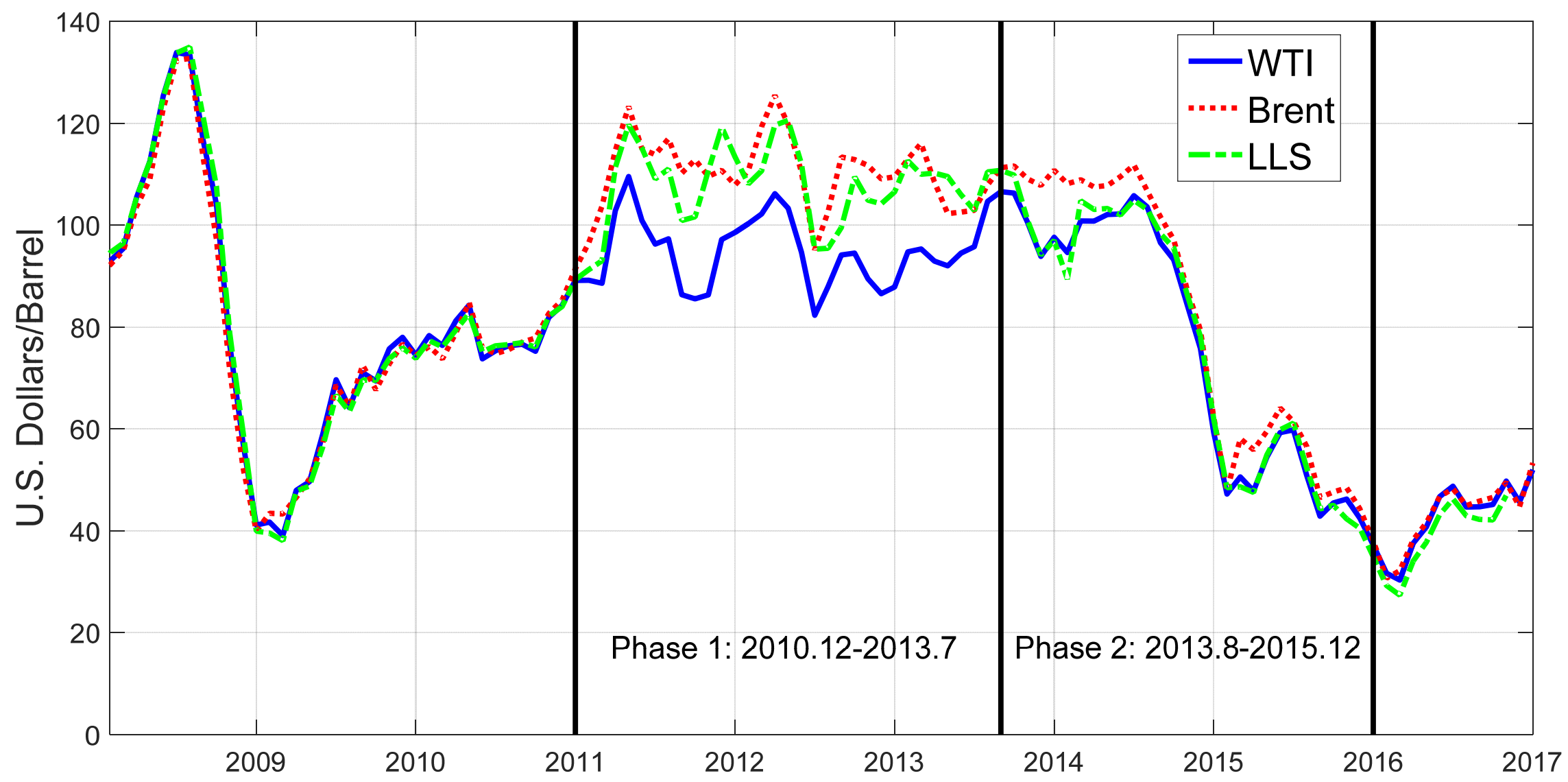

NOTES: All data are from the U.S. Energy Information Administration. 
Figure 4. Cumulative Effect of Oil Demand and Oil Supply Shocks on the Real Price of Oil, 2014.1-2015.8
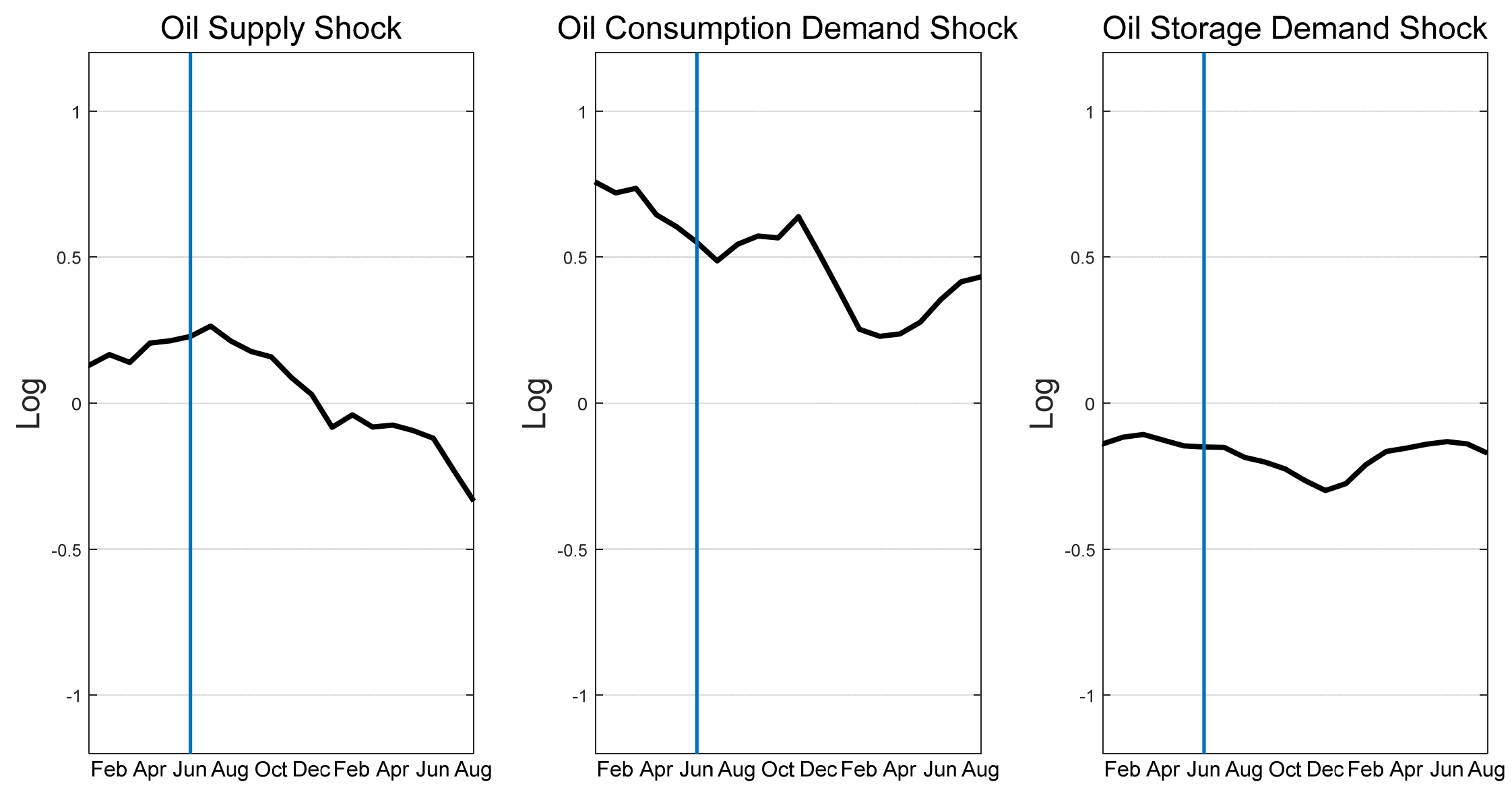

NOTES: The underlying structural model is constructed as in Kilian and Lee (2014), except the estimation sample has been updated to August 2015 (see Kilian 2017). The real price of oil is expressed in log deviations from the long-run average real price of crude oil. Each subplot shows the extent to which the shock in question moved the real price of oil up or down since January 2014. The vertical line marks June 2014. All three shocks contributed to the decline in the real price of oil after June 2014, especially shocks to oil supply and oil consumption demand. 
Figure 5. Actual Level of World Oil Production and Counterfactual Level in the Absence of the U.S. Tight Oil Boom

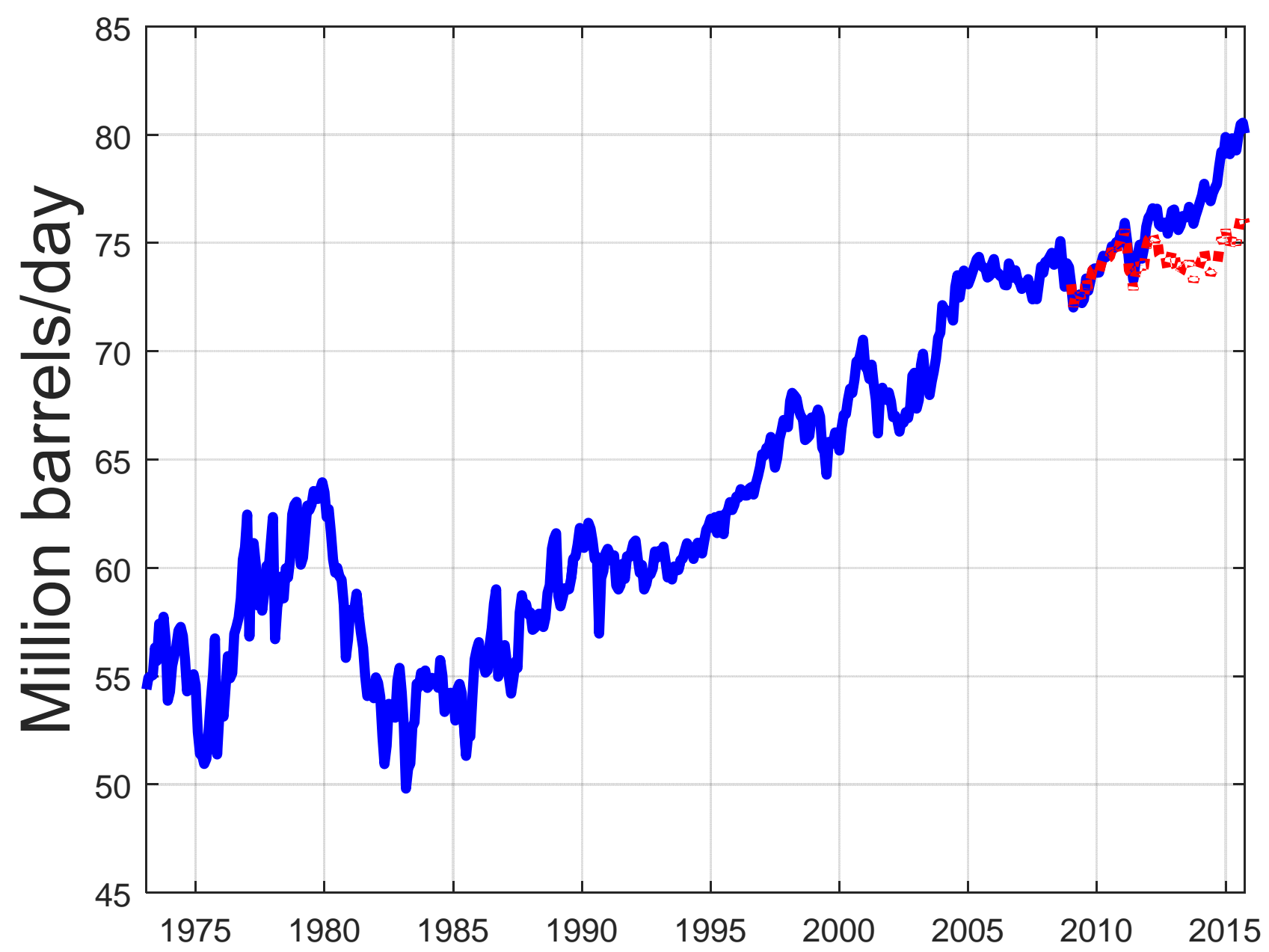

NOTES: The counterfactual level of world oil production is obtained by subtracting U.S. tight oil production from global oil production, as reported in the U.S. Energy Information's Monthly Energy Review, starting in November 2008. 
Figure 6. The Impact of Tight Oil Production on the Brent Price of Crude Oil

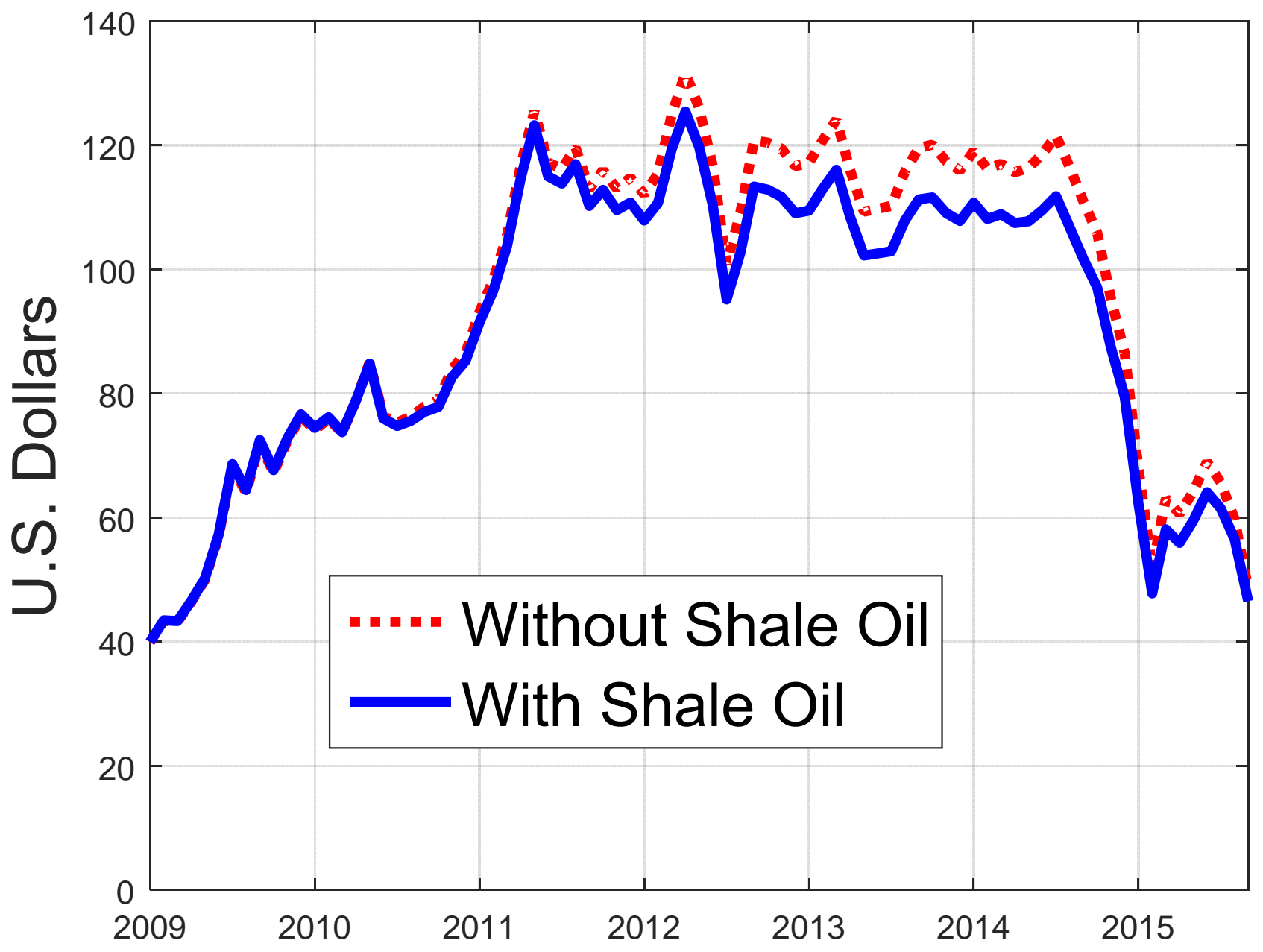

NOTES: The counterfactual Brent price is based on estimates in Kilian (2017). 